\title{
Impact of Information and Communication Technology on Acquiring the Literacy Skills outside the Classroom among Adults in Nsukka Urban
}

\author{
Ngozi Justina Igwe \\ Department of Adult Education and Extra-mural Studies, Faculty of Education, University of Nigeria, Nuskka, Enugu \\ State, Nigeria \\ Goodluck Chinenye Kadiri \\ Department of English and Literary Studies, Faculty of Arts, University of Nigeria, Nsukka, Enugu State, Nigeria \\ Joekin Ekwueme \\ Department of English and Literary Studies, Faculty of Arts, University of Nigeria, Nsukka, Enugu State, Nigeria
}

\begin{abstract}
The study investigated the impact of Information and Communication Technology on acquiring the literacy skills among adults outside the classroom in Nsukka urban. It sought to discuss the roles ICT plays in developing the literacy skills among adults. The study was anchored on the Piaget's Constructivist Theory of Learning. The study adopted a descriptive survey design. Using the Random Sampling Technique, one hundred participants were selected for the study. A twelve-item structured interview was developed and administered to these participants directly. The data were analyzed quantitatively using the frequency count and percentage method, duly represented in figures. The results showed that ICT plays a vital role in enabling adults who skipped being taught the skills of reading and writing formally in a conventional classroom and those with reading and writing difficulties acquire and develop these skills. The study suggested that adults should self-educate themselves by constantly using ICT facilities.
\end{abstract}

Index Terms - ICT, English acquisition, literacy skills, reading, writing, constructivist theory

\section{INTRODUCTION}

Information and Communication Technology (ICT) occupies the center stage in virtually every aspects of human existence. Okoro (2008) defines ICT as a means of accessing or retrieving, storing, transferring, processing and sending ideas, perception or information as well as provide access to Knowledge. In the words of Shittu and Shittu (2013) as cited in Ossai, Uzoegwu and Egbe (2017), ICT refers to all forms of evolving technology that help in facilitating information collection, processing, usage, transfer, storage, retrieval, sharing and interpreting information. Ezegbe, Okeke, Ome, Onah and Achebe (2017), however, argue that "the emergence of ICT has revolutionalized the way information is accessed, processed, stored, retrieved and disseminated within organizations or across the world." This argument stands in contradistinction with the traditional method of accessing, processing and disseminating of information decades ago. A good example is a situation where there is a conventional teacher who is teaching in a conventional classroom using one of the traditional methods of instructional delivery. Yenle (2018) adds that "the role of technology cannot be overemphasized as it can provide a significant plus to many conventional tools such as boards, textbooks, cassette, video players, etc," The advent of ICT in Nigeria has, however, changed the methods of doing things. In fact, ICT has introduced innovative ways of handling and solving the societal problems. It occupies a center stage at workplaces, schools, industries, firms, social life, to mention just these; thereby reducing the world to a global village. Ezegbe, Okeke, Ome, Onah and Achebe (2017) mentioned that laptops, video machine, multimedia projectors or power points, digital cameras, internet, social media, computer networks, telephone, tablets, Skype, You Tube etc. are some ICT tools that aid learning because of the various roles they play in simplifying learning of all types.

Scholars have established that ICT plays a vital role in teaching and learning of the English language in schools, colleges and universities (Ezegbe, Okeke, Ome, Onah \& Achebe 2017; Ossai, Uzoegwu \& Egbe, 2017; Yenle, 2018). English, in itself, is the world's most famous language. In Nigeria, for instance, English is the language of social mobility. It partly plays the role of a national language because of Nigeria's multilingual nature and her inability to assign this role to any of her indigenous languages. More so, in Nigeria, English is the language of the Media, Legislature, Education, Business, Aviation, Science and Technology, Politics, to mention but a few (Ngonebu, 2008; Onuigbo \& Eyisi, 2008). These scholars, in one way or the other, have posited that English serves as the second 
language of a multilingual Nigeria; it also serves as the official language of the nation. Most importantly, Onuigbo and Eyisi (2008) argue that English, as a compromised language, is a strong uniting factor among Nigerians who speak different languages. They go further to add that "to speak the same language is to express solidarity among the people who speak the language that cuts across tribal boundaries, promotes a feeling of a single community and therefore, serves as that great tradition which enhances the development of social ideal and cultural identities among the citizens" (p. 45).

The aforementioned arguments drive us to further argue that since English serves these functions in Nigeria then it is pertinent to create a platform that would help the adults who, due to one reason or the other, skipped formal education or adults who are termed 'slow learners', to acquire basic knowledge in the use of English, especially the skills of reading and writing in English. Unlike listening and speaking; reading and writing are the two language skills that need to be learned formally. This perhaps explains why Lawoli, Shaibu and Mohammed (2003) contend that "reading is an essential skill that must be acquired and developed in order to enhance our knowledge of the content of books, projects, articles etc." They state further that "without reading, we cannot understand or appreciate the content of any writing." Reading, in its self, entails the ability to interpret print while writing is the ability to produce print. ICT appears to be the best platform that would enable these adults to acquire the rudiments of reading and writing in English in the twenty first century in Nigeria and beyond. Nwachukwu, Okop, Imo \& Nwizu (2017) explicate that "time has proven that education has gone beyond the walls of classroom or school compound as other effective channels like the mass media and social media, are being used to dispense information and acquire knowledge." Ezegbe, Okeke, Ome, Onah and Achebe (2017) corroborate that "ICT has simplified education through the application of electronics media, internet among other ICT devices. There is a plethora of language programs in the electronic media, social media and the web that contributes to educate educational disadvantaged adults who have the desire to learn. For example, Ammanni and Aparanjani (2016) explain that ICT facilities such as laptops, iPods, tablets, smart phones have made English language learning easier. Ossai, Uzoegwu and Egbe (2017) further explain that "ICT helps learners to process information on their own, since institutionalized education is not enough to make learners keep up with the continues changes." (p. 205). Learning in itself, is an everlasting exercise since there is no end to it.

Importantly, Nigeria literacy indices were put at $62.2 \%$ as at 2018 by UNESCO Institute for Statistics. This record showed a slight geometric increase of $10.94 \%$ against what was recorded in 2008 . This implies that $37.02 \%$ of the nation's population lacked literacy skills. According to UNESCO, adult literacy is the percentage of people ages 15 and above who can both read and write with understanding of a short simple statement about their everyday life. UNESCO, recently, defines adult literacy as the ability to identify, understand, interpret, create, communicate and compute, using printed and written materials associated with varying contexts. However, ThisDay Newspaper of April 12, 2019 reported that the National Commission for Mass Literacy, Adult and non-formal Education (NMEC) had said that about $35 \%$ of the nation's adult population was illiterate. The commission went ahead to reiterate that literacy is so critical to national development that it should, perhaps, be second only to health. Particularly, Legit.com, an online news platform puts adult literacy index for Enugu State for 2018 at 65.0\%. This, perhaps, suggest that about 35\% of adults (excluding youths) in Enugu State are wallowing in illiteracy. The preceding figure, to say the least, is too large to be ignored. So, with the proliferation of ICT facilities such as the social media, web and You-Tube, there seems to be a new way through which these adults could learn or develop the skills of literacy. According to the findings of the National Literacy Survey (2010) as reported by National Bureau for Statistics, close to half (47.4\%) of the illiterate population of Nigeria would naturally like to attain the status of a literate person. All these, therefore, coalesce to inform our desire to attempt a study on the impact of ICT on acquiring the literacy skills among adults outside the classroom in Nsukka urban.

On the contrary, this study is only delimited to ICT software facilities such as the social media, You-Tube and the web. These facilities, of course, go with their hardware counterparts (Laptops, smartphones and tablets). Other ICT tools such as radio, television, smart-boards, projector, simulation software, speed reading software, vocabulary software, educational games, tutorial software, desk publishing, drill and practice software, reference software, etc. were not covered in this study. Also, the study only covered two sets of participants: those that were educationally disadvantaged and those that were not educationally disadvantaged but had reading and writing problems. Thirdly, the literacy skills, as defined by this study, did not cover computing; it only covered reading and writing. Lastly, only aspects of quantitative analysis were adopted in the interpretation of data.

\section{A. Statement of the Problem}

What makes a person literate is his ability to read and write; although it may not necessarily be in English but in other languages recognized by the nation. In Nigeria, what makes a person literate is his ability to read and write in English. This may be attributed to the fact that English is the medium of instruction in Nigerian schools and it is the major medium of social interaction amongst Nigerians who speak different languages. There is, therefore, the need for all Nigerians, irrespective of their educational and social statuses to learn the fundamentals of English in order to effectively live and interact in the society. It is in the records, as we have explicated in the introduction above, that a good number of adults in Nigeria, especially in Enugu State had skipped formal education where they were supposed to learn how to read and write in English; and there are also a significant number of adults who had actually attended schools but still find it difficult to read and write effectively; then it appears that ICT (social media and web) is another 
platform where these adults can acquire English language education. By so doing, they would be able to both retrieve and produce information in print. No doubt, very many scholars had carried out researches on the use of ICT in education; particularly, they had investigated the application of this new technology in language studies. However, it is pertinent to state that these researches demonstrated how ICT could be applied in English language studies to students inside the classroom. The use of Computer Assisted Language Learning (CALL) and Computer Mediated Learning (CML) by language teachers in the classroom are good examples of such studies. It then appears as thus there is some sort of exclusion, adults who are educationally disadvantaged or those that have reading and writing difficulties that constitute a significant part of the nation have not been accounted for by various studies because they are not in the four walls of the classroom. This study, therefore, deviates slightly from the rest in that it tends to accommodate the impact of ICT on acquiring the skills of literacy skills among adults outside the classroom in Nsukka urban.

\section{B. Purpose of the Study}

The purpose of the study is to investigate the impact of ICT on acquiring the literacy skills among adults outside the classroom in Nsukka urban. Specifically, this study is designed to achieve the following:

i. To discuss the roles of ICT in developing reading and writing skills in English among adults outside the classroom.

ii. To examine the extent to which ICT helps to develop reading and writing among adults outside the classroom.

\section{Research Questions}

Two research questions have been developed to guide the study. The research seeks to answer the following questions:

i. What roles does ICT play in developing literacy skills among adults outside the classroom?

ii. To what extent could ICT develop these skills?

\section{REVIEW OF RELATED LITERATURE}

Research in ICT and language education is not entirely new because there are a myriad of contributions that have augmented the literature in this area of inquiry. It is, therefore, important to stress that many scholars and researchers had carried studies on the roles and contributions of ICT in language studies. These contributions have, to a large extent, shed more light on the innovative way of teaching and learning of language and language related disciplines. It is on the premise of the preceding statements that Okueso and Osijo (2017) investigated how teaching and learning of English could be improved via the application of ICT tools. These scholars discovered that computer software proved to be of paramount importance in teaching as well as learning of the English language. Secondly, the study showed that teacher's motivation could be significant in improving the utilization of ICT in instructional delivery. However, despite all these merits, the study revealed, among others, that in most schools, there nonexistence of ICT facilities; coupled with non-availability of locally made ICT programs. They suggested, among others, that teachers of English should be trained and retrained in using ICT in language studies in order to enable them achieve these goals.

In a similar study, Ghasemi and Hashemi (2011) explored what they perceived as the interface between ICT and new-wave in English instruction. The paper revealed, among others, that the utilization of ICT provided students with requisite real-life experience as ICT exposed them to the culture of the host communities where English was used as a modeled language. This submission is in agreement with that of Yenle (2018) who viewed ICT tool or Computer Mediated Communication (CMC) as a tool which enabled second language learners to sound more native-like when using English. More so, Ghasemi and Hashemi (2011) argued that using ICT tools such as email, blogs, video and conferencing facilitated students' interaction with the natives thereby improving their use of English. It was posited that ICT could be used to integrate the four language skills (listening, speaking, reading and writing). Just as in the presiding paragraph, these scholars, however, stated that ICT has some disadvantages but they concluded that, despite these disadvantages, teachers should consider new strategies in teaching using ICT.

The interest of language researchers in finding out how best ICT could be integrated in teaching English in secondary schools spurred Mafuraga and Moremi (2017) to do a research in this area. They discussed ICT vis-à-vis its roles in teaching English in Botswana junior secondary schools. Fifty-five teachers (55) were selected from eleven (11) schools in the Kweneng region as research participants. Questionnaires and interview were administered to these participants and their responses were analyzed quantitatively using the Likert's scale. The findings revealed that most teachers of English were not ignorant of the fact that ICT could be used in teaching English but the teachers themselves demonstrated lack of adequate knowledge in utilizing ICT in teaching English. The researchers suggested some useful hints that would promote the integration of ICT in English language class.

On the other hand, Khanon (2018), in an elaborate study, investigated the application of ICT in English classrooms in Dhaka. The objectives of the study were to unearth the significance of using ICT tools in English language classrooms and to discuss how these tools play a role in reshaping the teaching of English. Two research questions were formulated to guide the study. The research instruments deployed in eliciting data were structured questionnaires and interview which were made up of eleven (11) closed-ended questions and seven (7) open-ended questions. The data were analyzed using the quantitative approach. The results showed that ICT enabled students to have access to knowledge 
during English classes. Teachers affirmed that they deployed ICT tools in teaching which most of the times, yielded positive results. It was thus concluded that ICT supports language learning.

In another study, Ossai, Uzoegwu and Egbe (2017) investigated the effective utilization of ICT in the development of learners' autonomy in teaching and learning of English in Obollo Afor Education zone. The study aimed at determining teachers' level of competency in applying ICT strategies in teaching English. The design of the study was a descriptive survey. One hundred and fifty-eight (158) teachers of English in the zone made up the population of the study. A forty (40) item questionnaires was used to elicit data for the study. Similarly, four (4) research questions were developed to guide the study. The data were analyzed using the Mean and Standard Deviation. The results showed that there was a low level of competency in the use of ICT in teaching English. The results also showed that teachers of English do not always use the ICT strategies in teaching. The study suggested, among other things, that teachers should be trained and retrained in handling ICT facility in teaching various subject, especially, English. More so, ICT facilities should be made available in schools and policies that would guide their use in schools should be enacted.

Summarily, the present study differs slightly from the ones reviewed above in the sense that the study investigated the impact of ICT in learning and developing the literacy skills in English by adults outside the classroom; whereas the previous studies, as we have seen in this section, investigated the roles of ICT in teaching and learning of English in the classroom by the conventional students. Here, the emphasis in this study is that since other studies concentrated on the application of ICT in the classroom situation, this present study examined how ICT facilities could be applied to educationally disadvantaged adults outside the classroom which could help to acquire or develop the skills of reading and writing. This gap is what this study intends to fill thereby contributing to knowledge.

\section{THEORETICAL FRAMEWORK}

The study borrowed insights from Constructivist Theory of Learning (CTL) proposed by Jean Piaget as applied by Suhendi and Purwarno (2018) in a paper entitled "Constructivist learning theory: the contribution to foreign language learning and teaching." The theory has its root in Piaget's cognitive development and Vygotsky's structural theory. Constructivism, as pedagogical theory, explicated how individual construct their understanding of their own experience themselves. In other words, the theory is used to explain how individuals know what they know. Piaget argued that individuals construct new knowledge from their experiences through the process of accommodation and assimilation. Piaget further explained that "when individuals assimilate, they incorporate the new experience into an already existing framework without changing that framework" (Bhattacharjee, 2015). The theorist explained that accommodation, on the other hand, is the process of reframing one's mental representation of the external world to fit new experiences. Suhendi and Purwarno (2018) summed that "constructivism views the formation of knowledge as an active subject that creates cognitive structures in their interactions with the environment" (p. 89).

The adopted theory suits the present study because it helps to shed more light on how adults learn or acquire experience through technology. According to the theory, people learn independently through experience. The quest to learn how to read and write may have spurred some educationally disadvantaged adults in Nsukka urban to constantly interact with ICT facilities in order to gain experience. This may be translated to mean that adults may manipulate various ICT tools so as to learn the basic skills of reading and writing.

\section{RESEARCH METHOD}

The study adopted the descriptive survey research design. This design is considered most appropriate for this study because it is used in investigating and describing phenomena in their natural settings so as to examine the true nature of the problem under study. A survey is one in which a group of people or item is studied by collecting and analyzing data from only a few people or item considered to be representative of the entire group (Nworgu, 2015). The population of this study comprises all the educationally disadvantaged adults and persons with reading problems in Nsukka urban. This research area is located in Nsukka Local Government Area in Enugu North Senatorial zone of Enugu State, Nigeria. Through the use of the Simple Random Sampling Technique, one hundred (100) participants (adults) were selected as a representative sample for the study. To answer the two research questions, a twelve-item structured interview was developed and administered to these participants directly by researchers in order to elicit participants' choices of answers which are represented using various options. The choice of the structured interview, however, was informed by our desire to give all our participants a fair representation because it was obvious that some participants may not still be able to read and write effectively. But before then, the instrument was validated by two experts in the Faculties of Education and Arts. They affirmed that the instrument was valid because it was capable of measuring and achieving the general and specific objectives of the research. The data were analyzed quantitatively using the frequency count and percentage method, duly represented in bar, line and pie charts, respectively.

\section{RESUlTS}




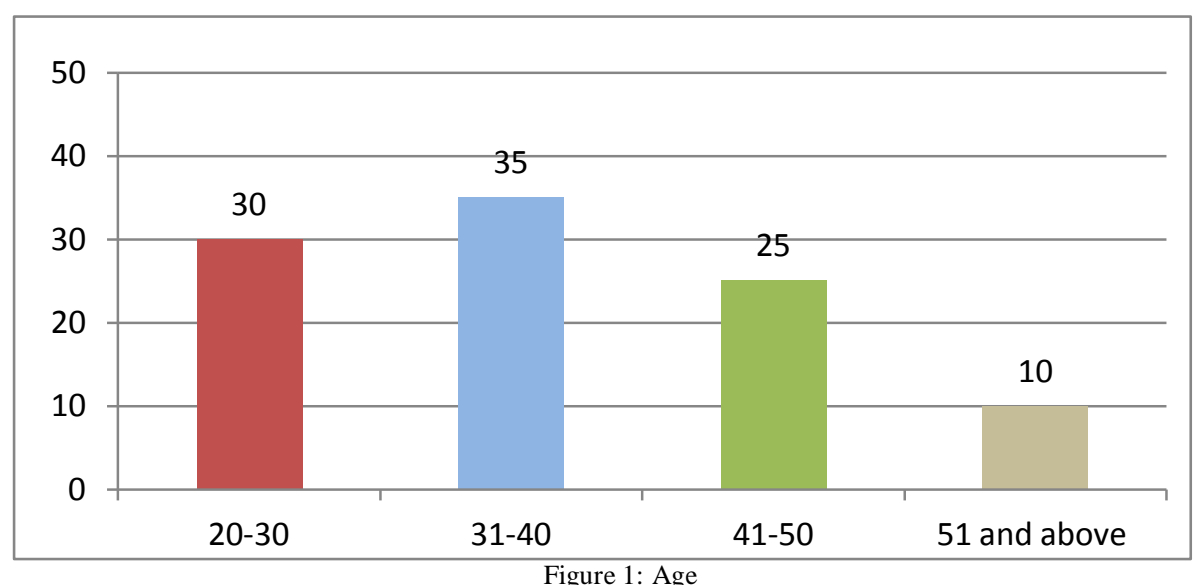

Figure 1 showed that the thirty (30) participants, representing 30\% fell within the age bracket of 20-30; thirty five (35) participants, representing 35\% fell within 31-40 age bracket; twenty five (25) participants, representing $25 \%$ fell within 41-50 age bracket, while ten (10) participants, representing $10 \%$ fell within the age bracket of 51 and above. From the data, those participants that fall between ages 18 to 40 (younger adults), representing $65 \%$ supersede the number of participants between the ages of 41 and above (older adults), representing $35 \%$ in this research. This statistic implies that younger generation makes use of ICT facilities more than the older generation of people.

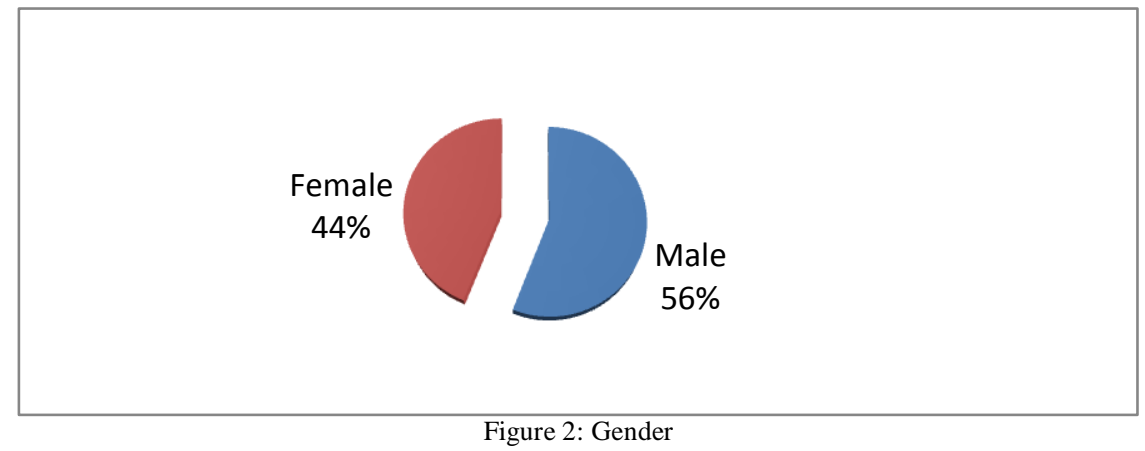

Figure 2 showed that fifty-six (56) male, representing $56 \%$ of the research sample and forty-four (44) female participants, representing $44 \%$ were used in the study. From this result, the male participants were higher in number than their female counterpart.

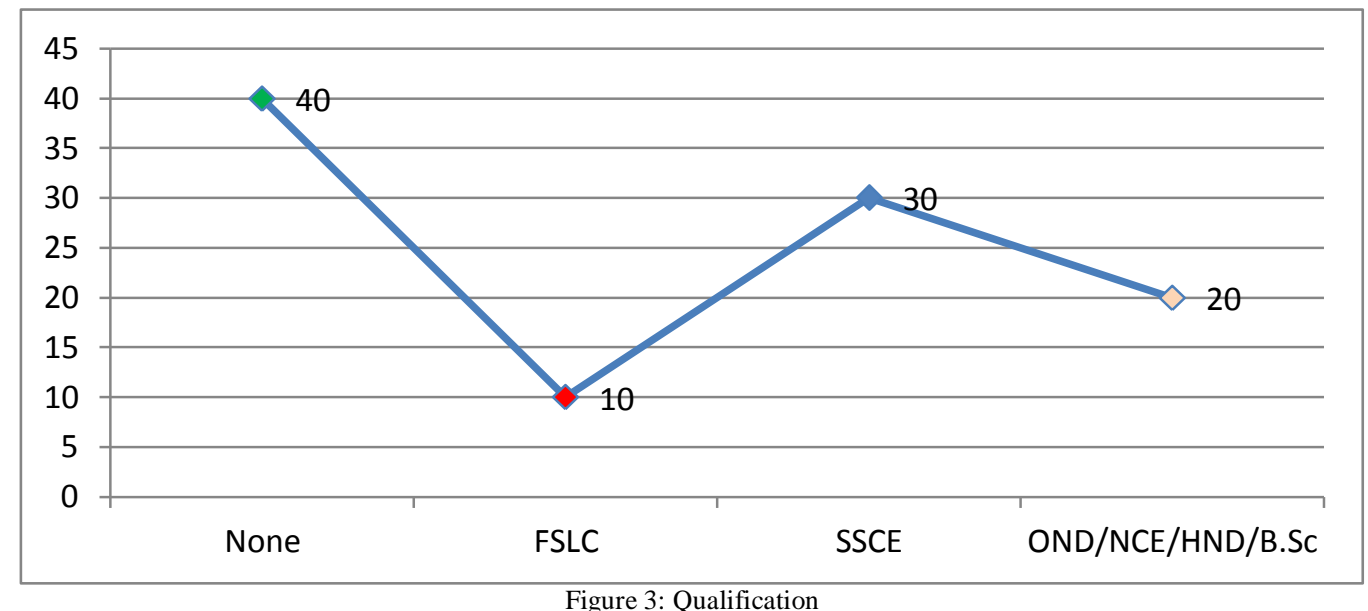

Figure 3 showed that forty (40) participants, representing $40 \%$ of the research sample did not have any educational qualification; ten (10) participants, representing 10\% had FSLC; thirty (30) participants, representing 30\% had SSCE; while twenty (20) participants, representing $20 \%$ had OND, NCE, HND or B.sc. From this statistics, the percentage of participants who were educationally disadvantaged (those that did not attend any school) was put at forty (40). Although this figure is not greater than the number of those that had privilege to attend school, however, this figure, to say the least, is too large to be ignored. 


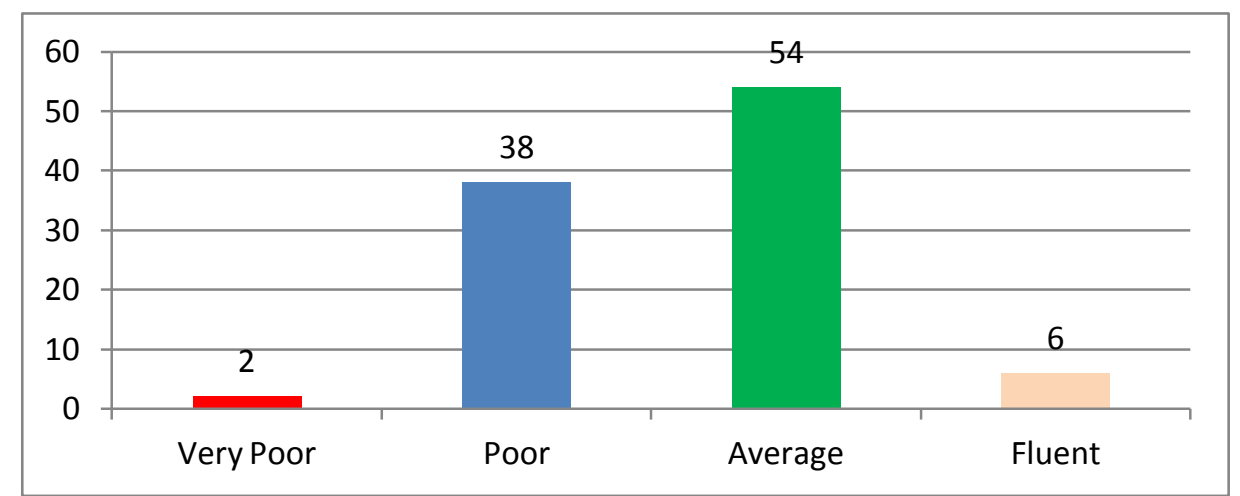

Figure 4: Rate your skills of reading and writing prior to your use of ICT tools such as social media and YouTube.

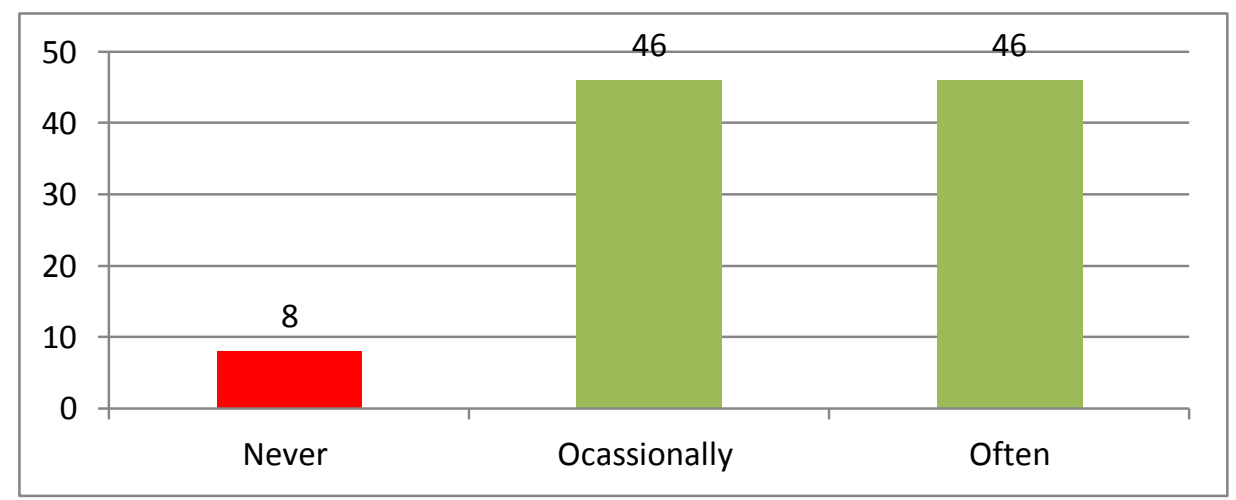

Figure 5: You often visit the social media and You-Tube

The results in figure 4 above showed that two (2) participants, representing $2 \%$ said that they had very poor reading and writing skills before they started using social media and You-Tube. Similarly, thirty-eight (38) participants, representing 38\% said that their reading and writing skills were poor. Fifty-five (54) participants, representing 54\%, on the other hand, said that they were average readers and writers; while only six (6) participants, representing $6 \%$ said that they were fluent readers and writers. From the foregoing, although $60 \%$ of the research participants were either average or fluent readers and writers, however, $40 \%$ of the same research participants had reading and writing difficulties prior to their use of the ICT facilities.

The results in figure 6 above showed that eight (8) participants, representing $8 \%$ had never used the social media and You-Tube. On the contrary, forty-six (46) participants, representing $46 \%$ occasionally used the social media and YouTube. Another forty-six (46) participants often used the social media and You-Tube. Suggestively, ninety-two (92) participants, representing $92 \%$ were familiar with these ICT tools.

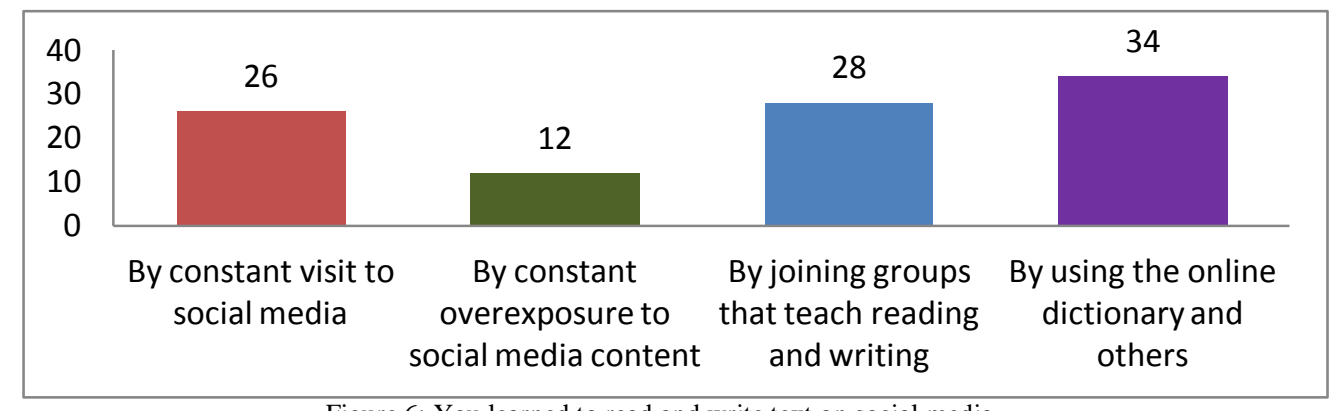

Figure 6: You learned to read and write text on social media.

The results in figure 6 above showed that twenty six (26) participants, representing 26\% agreed that they learned how to read and write by their constant visit to social media; twelve (12) participants, representing $12 \%$ said they learned these skills by constant overexposure to social media content; twenty eight (28) participants, representing $28 \%$ revealed that they learned skills by joining reading and writing groups; while thirty four (34) others, representing $34 \%$ believed they learned the skills of reading and writing through using the online dictionary, reading articles online, sending and receiving SMS, etc. From the foregoing, 66\% of the research participants learned or improved their skills of reading and writing through the social media; the remaining $34 \%$ learned through other ICT platforms. 


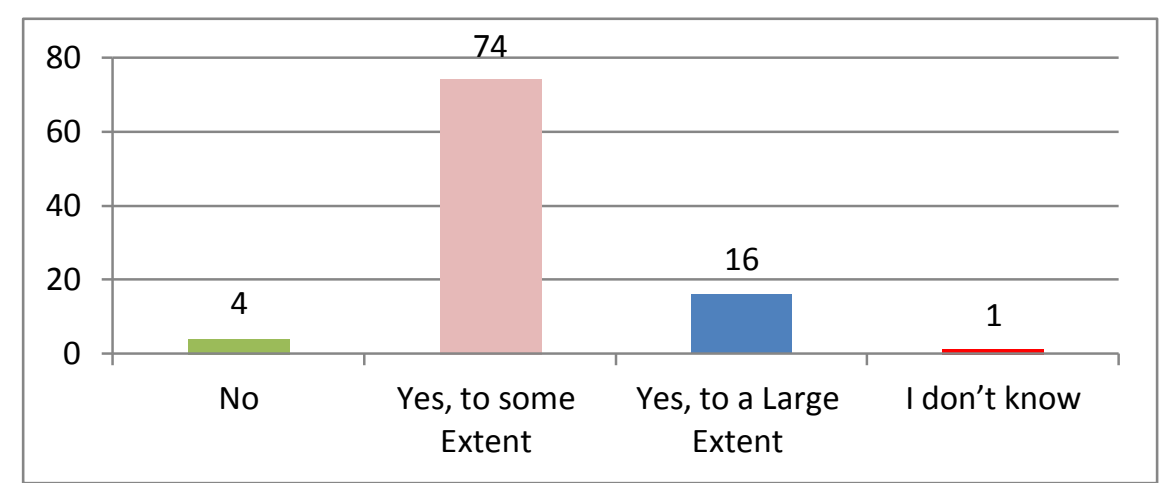

Figure 7: Your exposure to social media like Facebook and Whatsapp helped improve your reading and writing ability

Figure 7 above showed that four (4) participants, representing 4\% were of the opinion that their exposure to Facebook and Whatsapp applications did not improve their reading and writing skills. However, seventy-four (74) participants, representing $74 \%$ agreed that these applications helped them to acquire or improved their reading and writing skills to some extent. Similarly, sixteen (16) participants, representing $16 \%$ agreed that these applications improved their reading and writing abilities to large extent. One (1) participant is, however, undecided as to whether the applications helped improve her reading and writing abilities or not. These results suggested that $95 \%$ of the overall participants agreed that these applications did help in improving reading and writing skills. This result also confirmed that the social media play an important role in helping adult acquire or develop their reading and writing skills.

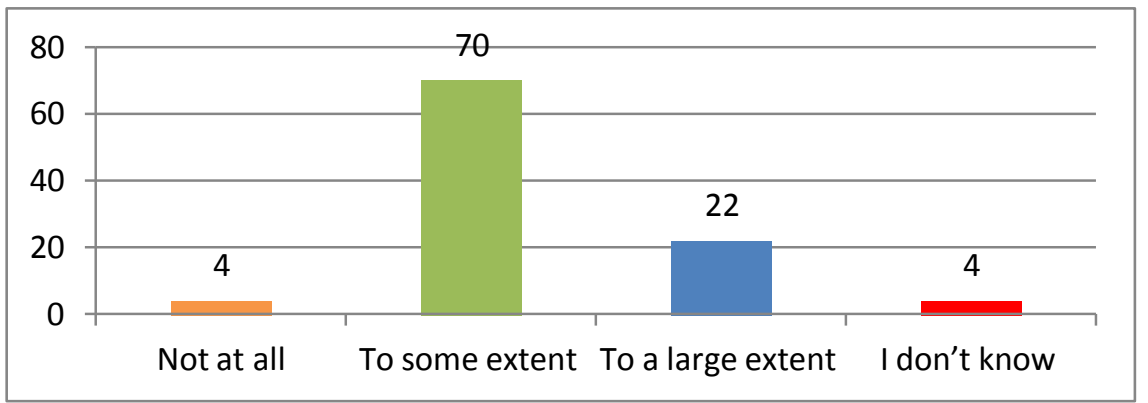

Figure 8: Your exposure to social media contents enabled you to acquire, pronounce and write new English words.

The results in figure 8 above showed that four (4) participants, representing $4 \%$ did not agree that their exposure to the social media contents aided them to acquire, pronounce and write new words. On the contrary, seventy (70) participants, representing $70 \%$ of the overall research sample agreed to the proposition but they said that it aided them to some extent. In a similar way, another twenty (20) participants, representing $20 \%$ contended that these platforms aided to acquire, pronounce and write new words to a large extent. On the other hand, the remaining four (4) participants were undecided. From the overall statistics, the majority of the participants represented by $92 \%$ agreed that the social media plays an important role in enabling adults to acquire, pronounce and write new words.

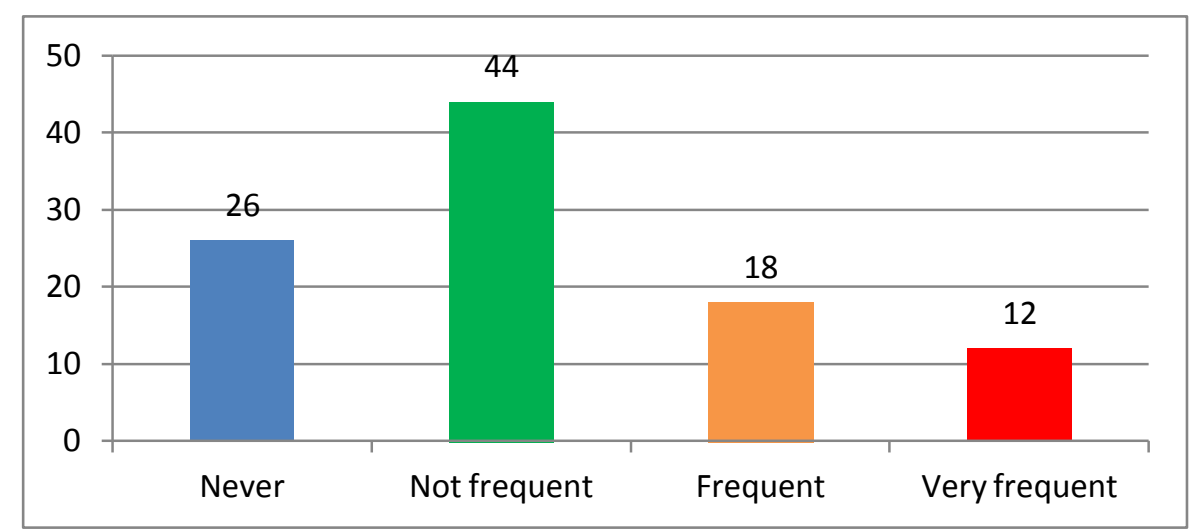

Figure 9: You frequently used You-Tube to learn how to read and write by listening to an online teacher

The data in figure 9 showed that twenty-six (26) participants, representing 26\% never used You-Tube to learn how to read and write. Another forty-four (44) participants, representing 44\% agreed that they did but not frequently. On the contrary, eighteen (18) participants, representing $18 \%$ agreed that they frequently used this platform to learn how to read and write. In a similar, twelve (12) participants, representing $12 \%$ said they used the platform very frequently to 
learn these skills. The overall results, therefore, suggested that $70 \%$ rarely used this platform to learn the skills of reading and writing. However, only $30 \%$ frequently used it to learn how to read and write by listening to an online instructor.

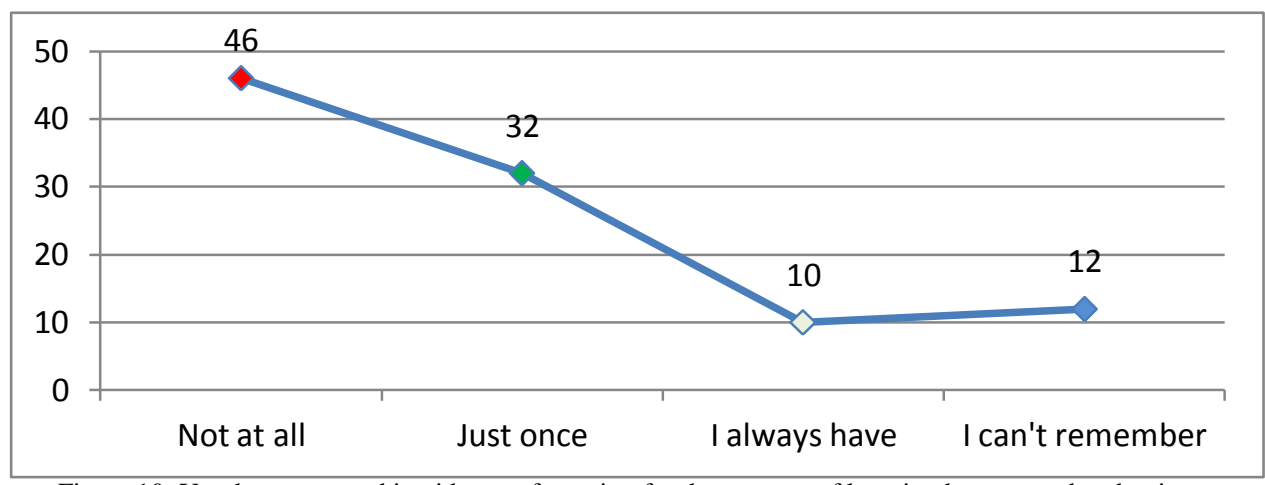

Figure 10: You have engaged in video conferencing for the purpose of learning how to read and write.

The data in figure 10 showed that forty-six (46) participants, representing $46 \%$ had never engaged in video conferencing for the purpose of learning how to read and write. Thirty-two (32) participants, representing $32 \%$ agreed they had done once. Ten (10) participants, representing 10\% agreed that they always did; while twelve (12) participant, representing $12 \%$ s were of the view that they could not remember. From this statistics, majority of the respondents, therefore, did not agree that they used video conferencing for the purpose of learning how to read and write.

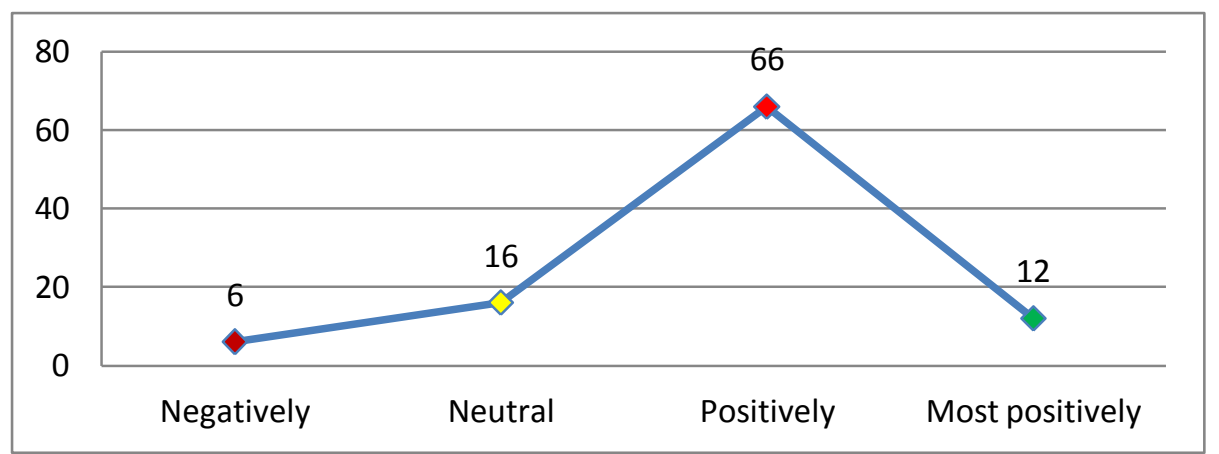

Figure 11: The ICT tools (social media, web, online dictionary, and You-Tube) had impacted your acquiring or developing of the basic skills of reading and writing.

Figure 11 showed that six (6) participants, representing 6\% were of the view that the ICT tools such as the social media, web, online dictionary, You-Tube, etc. had impacted negatively on their ability to read and write; sixteen (16) participants, representing 16\% were neutral; while sixty six (66) participants, representing 66\% agreed that these tools positively impacted the acquisition and development of these skills. In a similar vein, twelve (12) participants, representing $12 \%$ contended that these tools most positively impacted their learning and developing of these skills. The overall data showed that $78 \%$ of respondents which constituted majority agreed that the ICT tools had impacted positively to their acquiring or developing of the basic skills of reading and writing. From this statistic, it is evident, therefore, that ICT tools impacted positively to the acquiring of the basic skills of reading and writing.

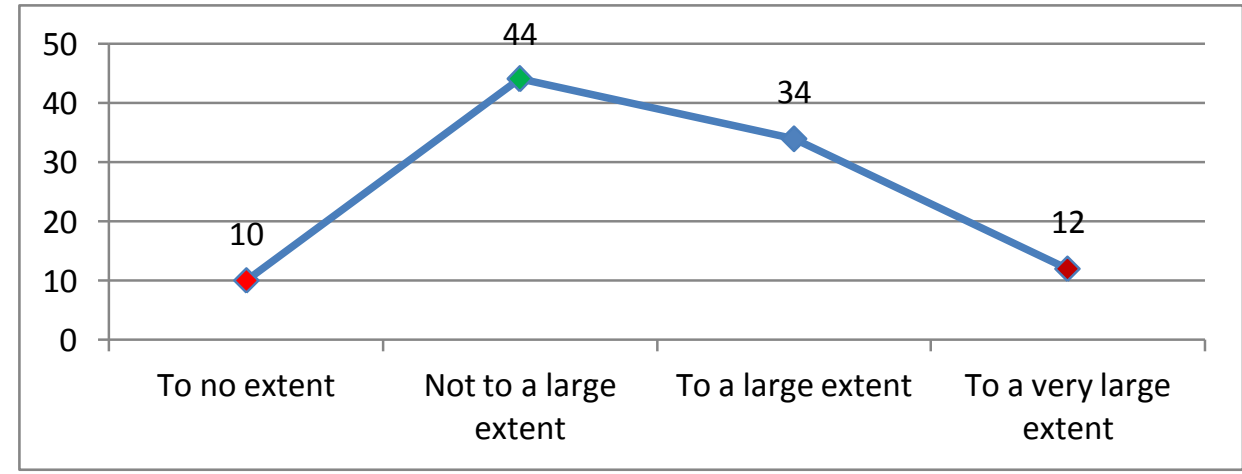

Figure 12: Rate the extent to which ICT facilities had helped you improve your reading and writing skills outside the classroom. 
The data in figure 12 above showed the extent to which ICT tools had helped improve the reading and writing skills of participants. Ten (10) participants, representing $10 \%$ were of the view that ICT tools had helped them acquire these skills to no extent; forty four (44) participants, representing $44 \%$ agreed that the tools had helped them acquire these skills, not to a large extent; thirty four (34) participants, representing 34\% were of the opinion that the tools had helped them to some extent; whereas twelve (12) participants, representing $12 \%$ strongly believed that the tools had helped them acquire these skills to a very large extent. From the foregoing, only $10 \%$ of the overall participants did not agree that these tools had helped them improve their reading and writing skills. However, the other $90 \%$ agreed that the tools had helped them.

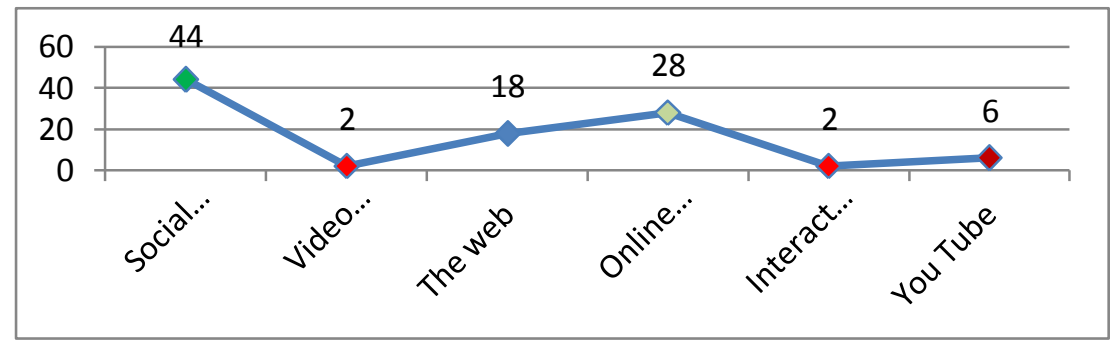

Figure 13: Choose the ICT tool that had helped you immensely in developing your reading and writing skills

The data in figure 13 showed that forty four (44) participants, representing 44\% of the entire research sample, chose the social media, two (2) participants, representing $2 \%$ chose video conferencing, eighteen (18) participants, representing $18 \%$ chose the web, twenty eight (28) participants, representing $28 \%$ chose the online dictionary, two (2) participants, representing $2 \%$ chose the interactive whiteboard, and six (6) participants, representing 6\% chose YouTube, as the ICT tool that had helped them immensely in developing their reading and writing skills. From the statistics, the majority of the participants chose the social media, followed by the online dictionary and the web in that order. The least chosen were the interactive whiteboard and the You-Tube.

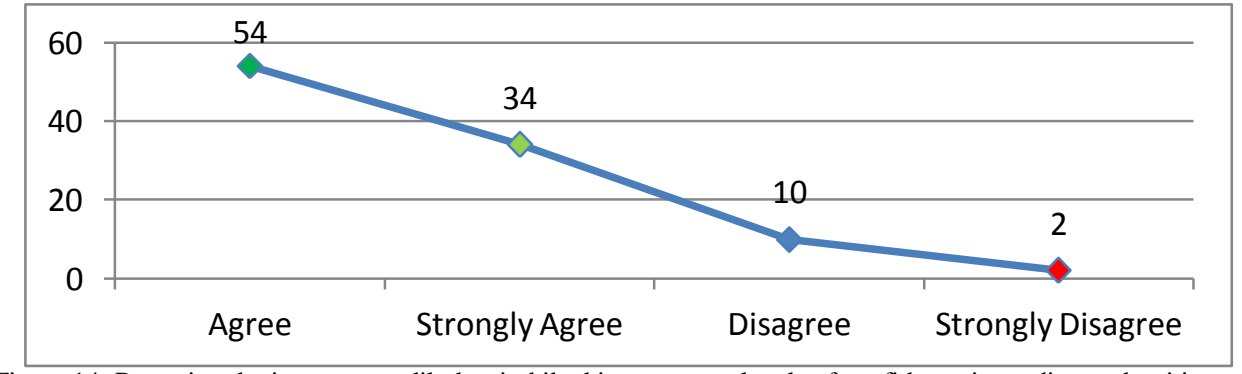

Figure 14: Browsing the internet steadily has imbibed in you some levels of confidence in reading and writing.

The data in figure 14 showed that fifty-four (54) participants, representing 54\% agreed that browsing the internet steadily had imbibed in them some levels of confidence in reading and writing. In a similar vein, thirty-four (34) participants, representing $34 \%$ strongly agreed to the same proposition. However, ten (10) participants, representing $10 \%$ disagreed that it did; while two (2) participants, representing $2 \%$ strongly disagreed. So, from this statistic, it is evident that the majority of the participants, represented by $88 \%$ agreed that browsing the internet steadily had imbibed in them some levels of confidence in reading and writing.

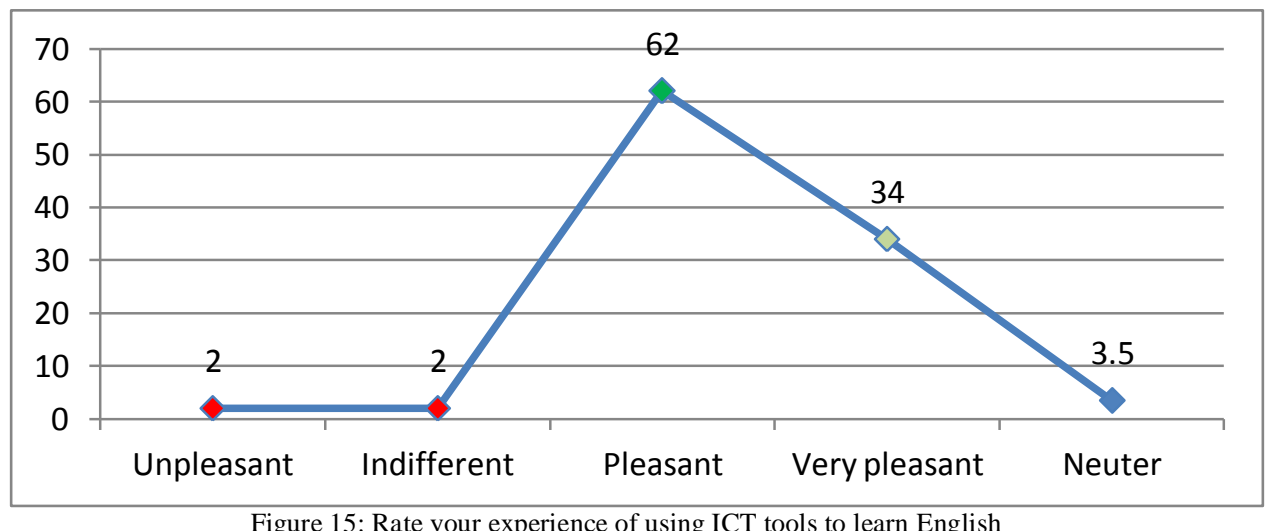

Figure 15: Rate your experience of using ICT tools to learn English

The data in figure 15 above showed that two (2) participants, representing $2 \%$ had unpleasant experience using ICT tools to learn how to read and write. Another two (2) other participants, representing another $2 \%$, on the other hand, 
were indifferent; while sixty-two (62) participants, representing 62\% had pleasant experience using these tools to learn and improve reading and writing skills. Similarly, another thirty-four (34) participants, representing 34\% had a very pleasant experience. From the foregoing, $96 \%$ of the overall participants had pleasant experience using these tools to learn how to read and write.

\section{Major Findings}

i. It is found that ICT plays a vital role in enabling adults who skipped being taught the skills of reading and writing formally in a conventional classroom and those with reading and writing difficulties, acquire and develop these skills.

ii. It is also found that ICT tools like the social media, You-Tube, online dictionary and the web have, to a large extent, positively impacted the acquiring and developing of reading and writing skills outside the classroom among adults in Nsukka urban.

\section{DISCUSSION}

The demography showed that majority of participants were mostly between the ages of 20 to 40 . By implication, the data revealed that most young people, irrespective of their social or educational statuses, use the ICT tools, especially the social media, You-Tube and the web. Although those between the ages of 50 and above were also accounted for in this study but they were not enough to be used to draw generalizations because they constituted a minority. In respect to gender, the results showed that both genders used the ICT tools, especially, the social and the web. It is, therefore, right to assert that both male and female adults use the ICT tools for many reasons; one of which is the learning and developing of the skills of reading and writing.

Meanwhile, the results showed that most participants were not proficient in reading and writing prior to their exposure to the use of social media and You-Tube; although a good number of them were averaged readers and writers. This drives us to assume that most adults visit the social media and other ICT platforms often or occasionally in order to achieve two principal goals: (i) to learn the skills of reading and writing as they surf through the social media contents (ii) to use the platform to develop their already acquired skills in order to be proficient. These goals may not be achievable if these goals preclude the times and lessons these visits to the ICT platforms offer. For example, if an action is done repeatedly over time, there is the tendency for acquiring of new knowledge or developing of the existing one. This further drives us to argue that our research participants learned or developed the skills of reading and writing through constant visit and exposure to social media content, and joining academic groups online. This agrees with Yousaf and Ahmad's (2013) submission that most young people are obsessed with typing on smart phones, laptops and other portable devices in the name of browsing the internet or chatting with friends and family online; in so doing, the skills of reading and writing are learned or developed.

Our findings also revealed other ways through which reading and writing skills could be learned outside the classroom; one of which is by listening to an online instructor on You-Tube; the other is by engaging in video conferencing for the purpose of learning these skills. It is, however, important to note that most adults in Nsukka urban were not aware that these platforms could be used to achieve these results. Although an insignificant number of them agreed that these platforms had helped them acquire and develop their literacy skills; nonetheless, it would not be valid if we use that to make generalizations because the majority of participants had never engaged in such instructions. In a similar way, the findings showed that participants were idiosyncratic as to which of the ICT facilities had helped them immensely in either acquiring or developing the skills of reading and writing. The commonest chosen options were the social media, the web and the online dictionary. The social media, according to our findings, was the most used platform designed for the developing or acquiring of the skills. The platform is very easy to navigate and surf. Most young people, irrespective of their educational backgrounds, explore it deeply to their advantage. The web is another platform that aid the learning or developing of literacy skills. Adults constantly read simple News and other articles online; by so doing, they learn new words and also become familiar with existing ones. Since reading as one of the language skills precedes writing, it is important to note that the same set of adults would begin to transpose what they have read to writing. The online dictionary is another ICT tool that contributes in strengthening the act of reading and writing. The tool is always available should a user needs it. It enables users to acquire, pronounce and use new words. This perhaps explains the reason why most participants agreed that these ICT facilities mentioned above had helped them improve their reading and writing skills outside the classroom, to a large extent. Most importantly, the findings showed that these tools impacted their acquiring and developing of the basic literacy skills positively.

\section{CONCLUSION}

ICT provides various electronic platforms that contribute in revolutionalizing the way information is accessed, stored and retrieved. Thus, ICT is utilizing electronic technologies to access educational curriculum outside of a traditional classroom. So, in what appears as self-education, younger and older generations of adults explore various ICT platforms such as the social media (Facebook, Whatsapp and Twitter), You-Tube, the web, online dictionary, to mention just these, for different social and academic purposes; one of which is to learn and develop the skills of reading and writing 
in English outside of the conventional classroom. These platforms enable adults who skipped being taught formally in a classroom, or those who have reading and writing problems to overcome these problems. This study has demonstrated that adults who are educationally disadvantaged or those that have reading and writing difficulties could actually acquire and develop their reading and writing skills outside the classroom through the use of Information and Communication Technology (ICT). This study, therefore, concludes that ICT plays a vital role in enabling adults who skipped being taught the skills of reading and writing formally in a conventional classroom and those with reading and writing difficulties, acquire and develop these skills. Again, ICT tools like the social media, You-Tube, online dictionary and the web have, to a large extent, positively impacted the acquiring and developing of reading and writing skills outside the classroom among adults in Nsukka urban. Based on the findings of this study, we, therefore, make the following suggestions:

a. Adults who are educationally disadvantaged or those that have reading and writing problems should continue to self-educate themselves by constantly visiting the social media and other ICT platforms.

b. These adults should, as a matter of necessity, visit You-Tube where educational contents on how to read and write are uploaded for users.

c. These sets of adults should always try to read articles online.

\section{ACKNOWLEDGEMENTS}

We thank the participants who made out time to answer our questions, those who supported us and those, in one way or the other, gave us ideas.

\section{REFERENCES}

[1] Ammanni, S. \& Aparanjani, U. (2016). The role of ICT in English language teaching and learning. International Journal of Scientific and Engineering Research 7.7, 1-7. http://www.ijser.org. (accessed 4/5/2020).

[2] Bhattacharjee, J. (2015). Constructivist approach to learning- an effective approach of teaching learning. International Research Journal of Interdisciplinary and Multidisciplinary Studies 1.6, 65-74. (accessed 4/5/2020).

[3] Ezegbe, B. N., Okeke,J. N., Ome, S.O., Onah, E. K. \& Achebe, C. A. (2017). Extent of utilization of information and communication technologies (ICT) in teaching Government in senior secondary schools in Awka education zone. International Journal of Studies in Education, 15.2, 175-192.

[4] Ghasemi, B. \& Hashemi, M. (2011). ICT: Newwave in English language learning/teaching. Procedia Social and Behavioral Sciences 15, 3098-3102.https://www.sciencedirect.com. (accessed 6/5/2020).

[5] Khanon, S. (2018). Application of ICT in English classroom: a study of the secondary schools in Dhaka. Master's Thesis, BRAC Institute of Languages.

[6] Lawoyi, M. A., Shaibu, V. A. \& Mohammed, J. A. (2003). Reading skills: a review of reading of students. NATECEP Journal of English and communication studies 1, 57-63.

[7] Legit.com. (2018). Literacy rate in Nigeria by State. www.legit.ng. (accessed 24/4/2020).

[8] Mafuraga, M. \& Moremi, M. (2017). Integrating information and communication technology in English language teaching: a case study of selected junior schools in Botswana. International Journal of Education and Development using Information and Communication Technology 13.1, 142-152.

[9] National Bureau for Statistics (2010). Report of the National Literacy Survey. www.nigerianstat.gov.ng. (accessed 20/5/2020).

[10] Ngonebu, C. L. (2008). Fundamentals of second language learning. Nsukka: Afro-Orbis Publication.

[11] Nwachukwu, R. U., Okop, E. O., Imo, C. O. \& Nwizu, S. (2017). Utilization of e-learning technologies in distance education programmes in Awka-South Local Government Area, Anambra State. International Journal of Studies in Education 15.2, 376385.

[12] Nworgu, B.G. (2015). Educational Research: Basic Issues and Methodology ( $3^{\text {rd }}$ ed.). Nsukka: University Trust Publishers.

[13] Okoro, N.F. (2008). Application of information and communication technology (ICT) in education instruction in Nigeria schools. International Journal of Educational Research 8.1, 135-143.

[14] Okueso, S. A. \& Osijo, Y.E. (2017). Improving teaching of English language through ICT for national curriculum consciousness: limitations of teachers in Nigeria. European Journal of English Language and Literature 5.5, 41-47. www.eajournals.org. (accessed 23/4/2020).

[15] Onuigbo, S. \& Eyisi, J. (2008). English language in Nigeria: issues and development. Nsukka: Global Publishers.

[16] Ossai, R. C., Uzoegwu, P.N. \& Egbe, C.I. (2017). English language teacher's utilization of effective ICT strategies in the development of learner autonomy for sustainable development. International Journal of Studies in Education 15.2, 203-215.

[17] Piaget, J. (1971). Biology and knowledge. Chicago: University of Chicago Press.

[18] Solomon, E. M. \& Gyang, C. J. (2003). The role of the computer in teaching English grammar at secondary school level. students. NATECEP Journal of English and communication studies 1, 109 -116.

[19] Suhendi, A. \& Purwamo, P. (2018). Constructivist learning theory: the contribution to foreign language learning and teaching. The $1^{\text {st }}$ Annual International Conference on Language and Literature 8795.https://www.researchgate.net/publication/324950056. (accessed 9/3/2020).

[20] Thisdaylive April 4. (2019). The glowing illiteracy in Nigeria.https://www.thisdaylive.com.(accessed 23/4/2020).

[21] Yenle, M.S. (2018). Role of computer mediated simulation (CMS) in the teaching and learningof oral English. Pankshin Journal of Language Education 4.1, 141-145.

[22] Yousaf, Z. \& Ahmed, M. (2013). Effects of SMS on writing Skills of university students in Pakiatan. Asian Economic and Financial Review 3.3, 389-397. www.aessweb.com/journal-detail.php?id=5002. (accessed 4/5/2020). 
Ngozi Justina Igwe is a lecturer in the Department of Adult Education and Extra-mural Studies of the University of Nigeria, Nsukka, Enugu State, Nigeria. She holds a PhD in Adult Education. Her area of Specialization is Extension and Distance Education. Her research interest is in Teaching Adults with Technology (ICT).

Goodluck Chinenye Kadiri is a Senior Lecturer in the Department of English and Literary Studies of the University of Nigeria, Nsukka, Enugu State, Nigeria. She holds a PhD in English Language. Her area of specialization is Applied Linguistics with research interest in Forensic Linguistics, English as a Second Language and Discourse Analysis.

Joekin Ekwueme holds a Master's degree in English Language and is doing a PhD programme in the Department of English and Literary Studies of the University of Nigeria, Nsukka. His research interest is in Text-linguistics, ESL and Applied Linguistics. 